\title{
Some aspects of the British Geological Survey's contribution to the war effort at the Western Front, 1914-1918
}

David G Bate ${ }^{1}$ and Andrew L Morrison ${ }^{2}$

\footnotetext{
${ }^{1}$ Honorary Research Associate, British Geological Survey, Environmental Science Centre, Nicker Hill, Keyworth, Nottingham NG12 5GG; email dgba@bgs.ac.uk

${ }^{2}$ Archivist, British Geological Survey, Environmental Science Centre, Nicker Hill, Keyworth, Nottingham NG12 5GG; email anrr@bgs.ac.uk
}

\begin{abstract}
The application of geology to warfare in regard to questions of water supply, ground conditions and access to strategic minerals has long been appreciated, and much has already been written on these aspects of the science. During the Great War of 1914-18 the services of the British Geological Survey, under the directorship of Aubrey Strahan, were called upon to advise on such matters both at home and abroad. Surviving archived files at the Geological Survey allow us to examine some rather more unexpected applications of the science, particularly in regard to the European theatre of war. These files provide only a partial record of the full range of war-related activities undertaken by the Survey, but they do reveal more especially the application of petrography to aircraft compass design, forensic geology, and the choice of stone for war graves.
\end{abstract}

Keywords: First World War; Western Front; forensic geology; petrography; water supply

\section{Introduction}

The present paper derives from a request made to the British Geological Survey by JeanClaude Porchier of the Association des Géologues du Bassin de Paris for information from the Survey's archives concerning its role in the Great War of 1914-18 in relation to the Western Front. An account written by the present authors will appear in French translation in a forthcoming book edited by Bergerat et al. (in press), which is due for publication in December 2017 as part of the French official centennial commemoration programme. The following account is an expanded version of that paper for the benefit of English language readers.

A partial record of the Survey's role in the Great War survives amongst files of correspondence maintained by Aubrey Strahan (Fig. 1), who was then the Survey's Director. Judging from the list of war-related activities that he drew up at the end of the war (Strahan 1919), it is apparent that the record preserved in these files is frustratingly silent on many of those activities. The authors have therefore selected for discussion only those topics for which adequate information exists in the Survey's files.

The year 2017 marks the hundredth anniversary of the foundation by Royal Charter of the Commonwealth War Graves Commission, and it seemed therefore appropriate to include a discussion of the Geological Survey's role in the selection of suitable stones for war graves and memorials erected in Belgium and northern France. For this purpose we were able to make use of files established by the Geological Survey Museum Curator, J. Allen Howe, 
which contain correspondence with the then Imperial War Graves Commission on suitable stones for war graves and memorials throughout the Commonwealth, covering the period 1918-1930.

\section{The Geological Survey on a war footing}

Sir Aubrey Strahan (1852-1928; created K.B.E. 1919) was Director of the British Geological Survey (Geological Survey of Great Britain as then styled) from January 1914 until his retirement in July 1920 (Flett 1928). Strahan's directorship corresponded with one of the most testing periods in the Survey's history, for the Great War of 1914-18 placed demands on the organisation for which it was largely unprepared. The Survey did not have war plans laid in advance and had to discover by experience what was required of it (Bailey 1952, 172173).

Following Britain's entry into the war on 4 August 1914, the Geological Survey was soon called upon to provide expert geological advice in respect of the British Expeditionary Force's theatre of activity in Belgium and northern France. Thus on 8 August Aubrey Strahan responded to a request from the War Office for the loan of geological maps of France and Belgium. In addition, advice was sought on obtaining temporary supplies of drinking water at short notice from superficial deposits and from the Upper Cretaceous chalks and Palaeogene sands and clays which crop out in the region. Strahan supplied some general guidance by analogy with geologically similar terrain in southern England (contained in a two-page typescript report: BGS Archives GSM/DR/St/A/3; see list of files at the end of this paper). This was followed a few months later by the publication of more detailed notes for the use of sanitary and water supply officers (Strahan 1914). In Strahan's response of 8 August the suggestion was made that 'It might be worth your while to consider the advisability of having one of our geologists with the troops to advise in the selection of the best spots for trials for water.' Not until April 1915 however was Strahan's offer acted upon by the War Office. Indeed, the British Army had no previous record of employing professional geologists as such; yet the problems of static battlefield conditions that arose at the Western Front from the end of 1914 would soon create a need for geological expertise on the ground (Rose \& Rosenbaum 1993a; Rose 1996).

At the outbreak of war, practically all members of Geological Survey staff of military age volunteered for service, and although a few were rejected from various causes, by the end of 1914 fifteen had joined the forces; by close of the following year the number of staff on active service had risen to twenty-five (Flett 1937, 162-163). This number represented a little more than one third of the workforce of the Geological Survey and Museum, which at that time totalled about sixty-eight personnel (GSM/DC/P/37). In his Summary of Progress of the Geological Survey for 1916 Strahan had to report that 'The continuance of the War and an increase in the number of special investigations which are required in connection with it and with industrial policy after it is over, have necessitated a temporary suspension in all districts of the normal work upon which the Survey has been engaged in late years' (Strahan 1917a). In the following pages we will examine some of these war-related activities in regard to the Western Front. 


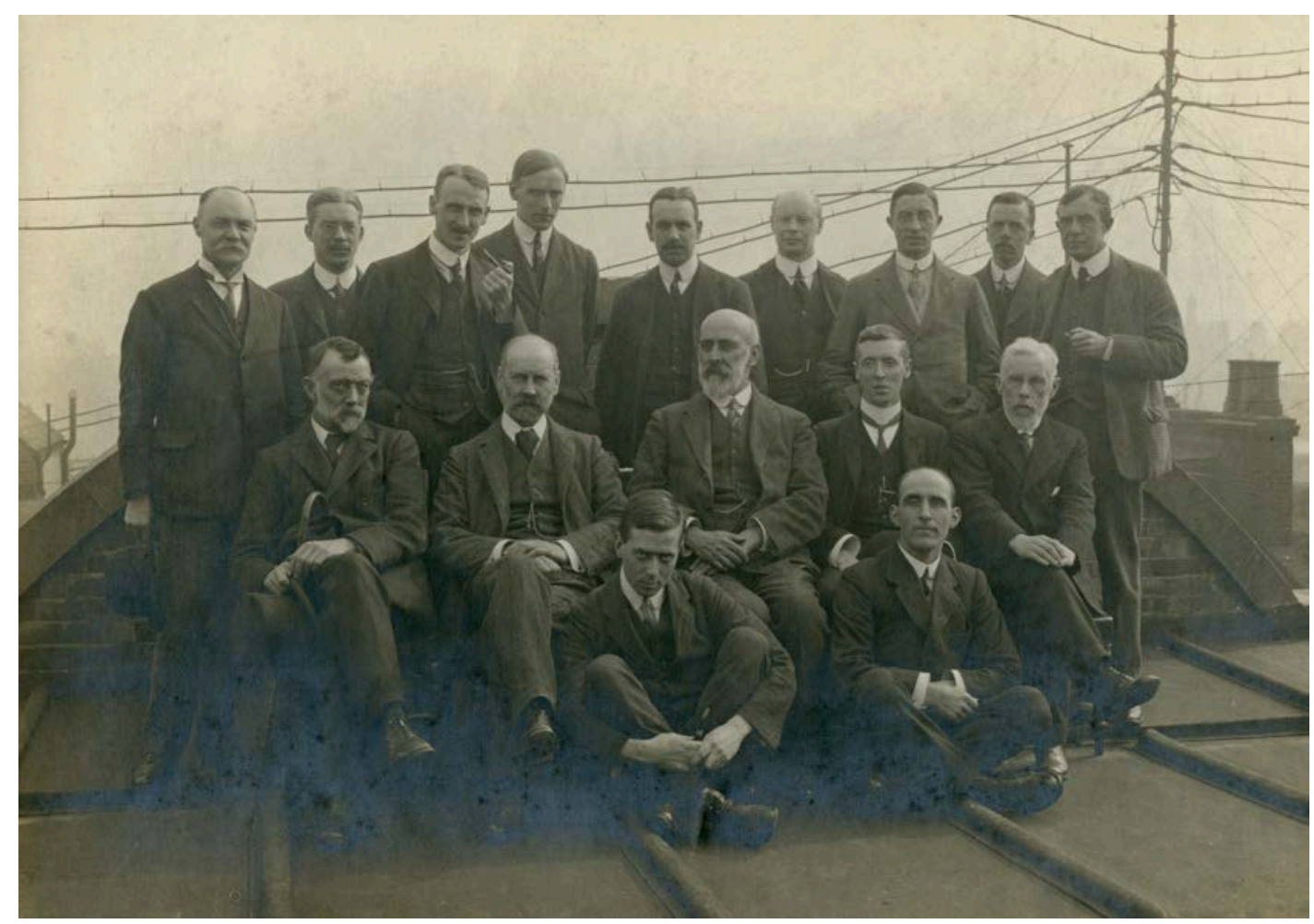

Fig. 1. Photograph taken on the roof of the Geological Survey and Museum, Jermyn Street, London, by Geological Survey Photographer, J. Rhodes, 1912 or 1913, showing a select group of London-based Survey geologists. Those mentioned in this account are as follows: H. H. Thomas (back row, middle); J. A. Howe (back row, fourth from right); A. Strahan (middle row, second from left); J. J. H. Teall (middle row, third from left). In passing we may note that R. W. Pocock (back row, fourth from left), E. E. L. Dixon (front row, right) and C. E. N. Bromehead (front row, left) all served in the forces. At the outbreak of war, C. B. Wedd (back row, last on right) was surveying in the Welsh borders in September 1914 when he was arrested at Oswestry after being mistaken for a German spy (British Geological Survey archives).

\section{Water supply at the Western Front}

The importance of water to the army is emphasised in the following quotation (Institution of Royal Engineers 1921, 13):

The adequate supply of water is of paramount importance in every phase of warfare. Men can fight, and continue to fight, in spite of a shortage of ammunition, for considerable periods; both men and animals can subsist for several days on a minimum supply of food, but both men and animals will break down in a few hours, and lose their spirit, condition, and power of resistance, unless they can obtain water in sufficient quantities, and of the necessary purity.

By the spring of 1915, the build-up of Allied troops at the Western Front had led to serious water supply problems. On 27 April the Secretary of the Board of Education (then the governing body of the Geological Survey) received a formal written request from the War Office for 'a report on the Geological conditions affecting the available sources of Water in Belgium and the North of France, both as regards superficial and deep-seated sources'. Strahan had already been informally approached by the War Office earlier that month with a view to greatly expanding the information supplied by him in 1914 (GSM/DR/St/A/11). He 
was now able to call upon the assistance of Professor Xavier Stainier of the University of Ghent, who had an intimate knowledge of the region's water supply and was then, as a consequence of the German occupation of Belgium, residing at St Leonards-on-Sea in Sussex (Rose 2015). The completed report (in typescript only) was despatched to the War Office on 16 July (Strahan 1915a). It was accompanied by a specially prepared geological compilation map of Belgium at a scale of 1:160 000, reduced from the published Carte Géologique de la Belgique at 1:40 000 scale (Strahan 1915b). The map was printed by the Ordnance Survey in six sheets (later five: Rose 2015) and supplied to the War Office in hand-coloured form (Fig. 2). This map was put to use in October 1917 when it became necessary to predict the effect of heavy shelling on ground conditions to the north and east of Passchendaele Ridge (Institution of Royal Engineers 1922, 35-37).
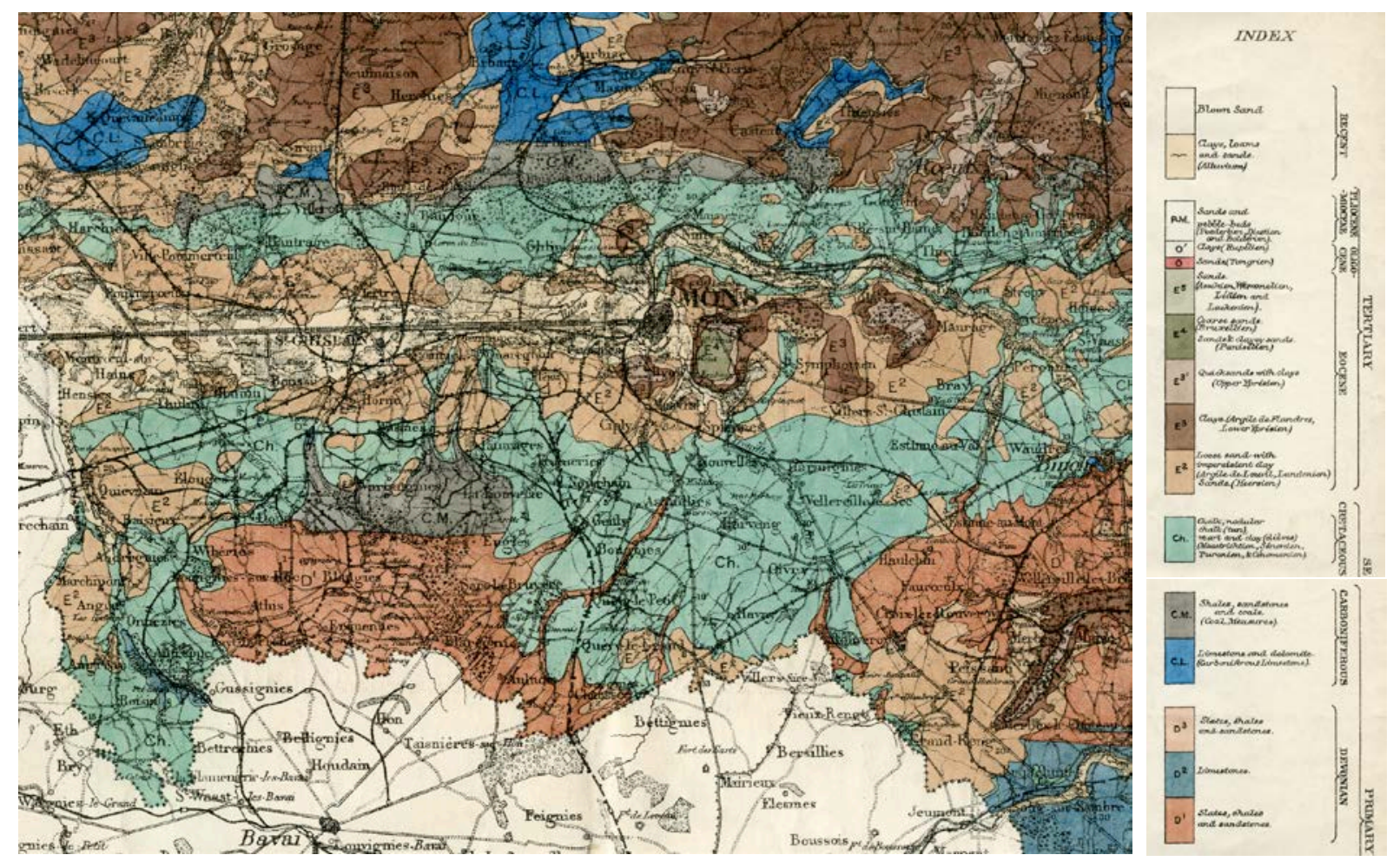

Fig. 2. Extract from Geological map of Belgium, scale 1:160,000; geological lines prepared and modified by Aubrey Strahan, Director of the Geological Survey of Great Britain, from the 1:40 000 scale Carte Géologique de la Belgique, sheet 5, 1915 (Library, British Geological Survey).

Among those Geological Survey staff who volunteered for active war service was W. B. R. King (Fig. 3), who was given a commission as a second lieutenant in the Seventh Battalion of the Royal Welsh Fusiliers on 21 September 1914 (Rose \& Rosenbaum 1993a; Rose 2012). Following the War Office approach to the Geological Survey in April 1915, Strahan recommended that King, as a former employee of the Survey, be trained for active service as a military geologist. King thus spent some weeks at the Geological Survey office in London looking over existing literature and assisting Strahan in the compilation of the abovementioned report (Fig. 4). In June, King proceeded overseas to take up the post of geologist with the Chief Engineer at General Headquarters (King 1919; Rose 2012). Strahan's completed report and maps were in King's hands by 28 July. There was some further 


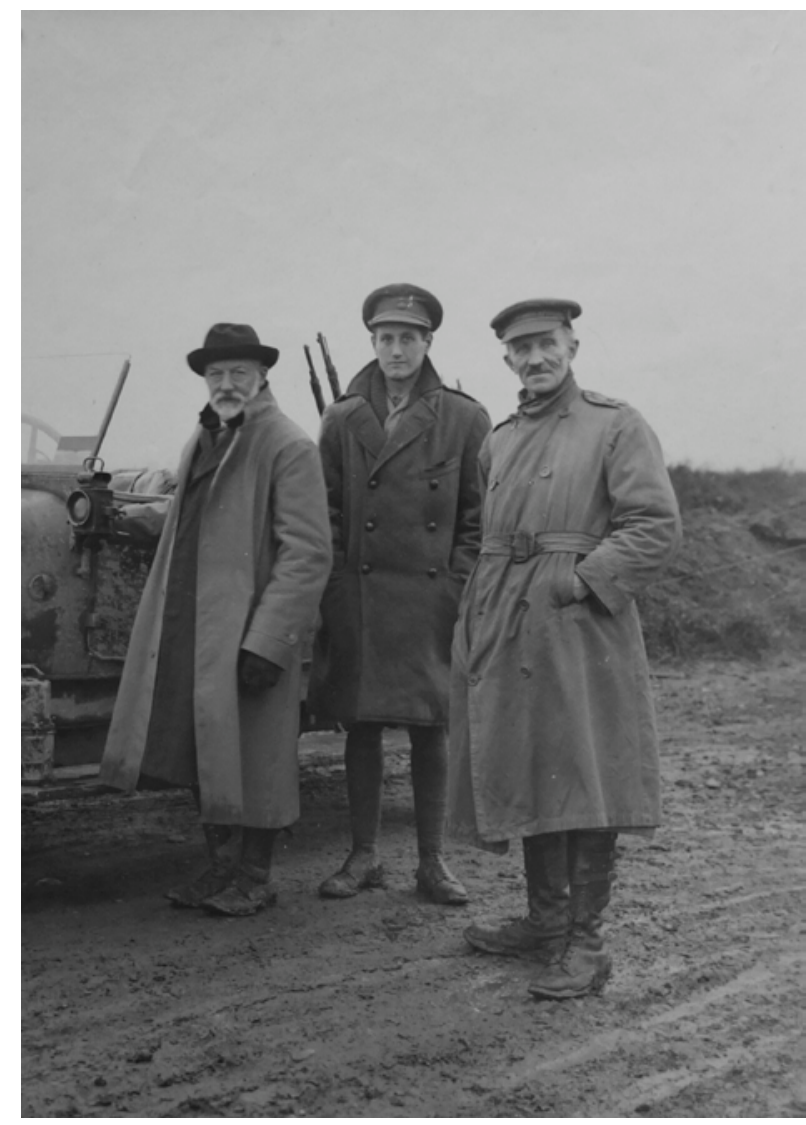

correspondence between them during April and May 1916, when King sought the advice of Stainier and Strahan on a provisional water supply map of enemy-held territory ahead of the British line in occupied Belgium (GSM/DR/St/A/16: includes a five-page typescript report of general remarks by Stainier, dated 27 April 1916). King's subsequent distinguished wartime career as a military geologist/hydrogeologist has been adequately documented elsewhere (e.g. Rose 2009, 2012) and need not be repeated here.

Fig. 3. Geologist Captain W. B. R. King (centre) with Charles Barrois, Professor of Geology at the University of Lille (left), and Australian geologist Lieutenant-Colonel T. W. Edgeworth David (right), on 26 November 1918 following the liberation of Lille (reproduced by kind permission of King's granddaughter, Jane Ritchie; caption details from Rose 2015).

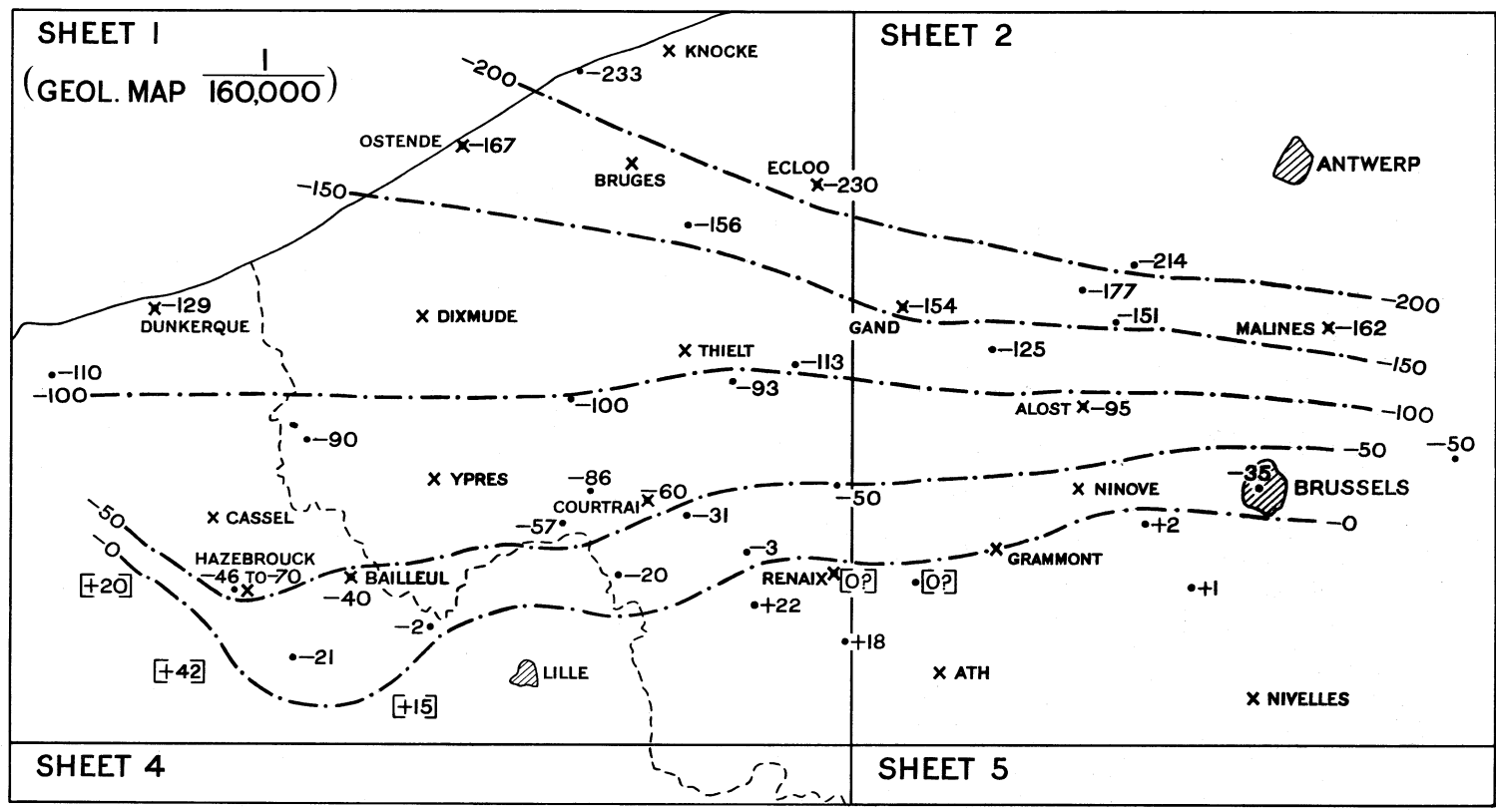

LINES OF LEVEL IN TOP OF LANDENIEN.

Depths to Landenien below sea-level are shown in metres thus -50 Height of ", above , " , , , , +18 Figures enclosed in square brackets $[42]$ are doubtful, owing to uncertainty as to the elevation of the ground.

\begin{tabular}{lcccc}
\multicolumn{5}{c}{ SCALE } \\
0,10 & 20 & 30 MILES \\
$0,11,10$ & 20 & 30 & 40 & 50 KILOMETRES
\end{tabular}

Fig. 4. Diagram prepared by W. B. R. King to accompany Strahan (1915a); the sheet numbers refer to the accompanying 1:160 000 scale map of Belgium. 


\section{Redesign of aircraft compass}

On 13 September 1916, possibly following an earlier informal approach, a request was received by the Survey from Lieutenant R. J. Bray, Admiralty Compass Department, for assistance in choosing an alternative material to sapphire for aircraft compass points and cups (GSM/DR/St/A/20). The task of determining by experiment the most suitable materials for compass bearings was given to Herbert H. Thomas, Geological Survey Petrographer (Fig. 1). Thomas reports that these bearings as then constructed consisted of a metal spindle carrying a rounded conical polished point of sapphire which worked in a cup of the same material. The points were found to frequently develop flaws and cracks, and occasionally broke down completely. The error lay in the use of material of equal hardness for both point and cup, and in the choice of a mineral which is notoriously prone to develop flaws under a state of strain such as might be brought about by aircraft vibration or sudden shocks.

Microscopic investigation was carried out on a large number of points and cups both before and after use, and photomicrographs were taken, some of which are reproduced in Bray's Pivots and caps in compasses (Bray 1917). In most cases the defects were attributable to flaws and inclusions in the original mineral. Other minerals tested were spinel, natural and artificial corundum, and agate. Points from two German Zeppelins were also examined. It was decided that sapphire should be retained as the material for the cup, and that agate, which is slightly less hard but extremely tough, should be used for the points. This combination proved to be entirely successful (Fig. 5).

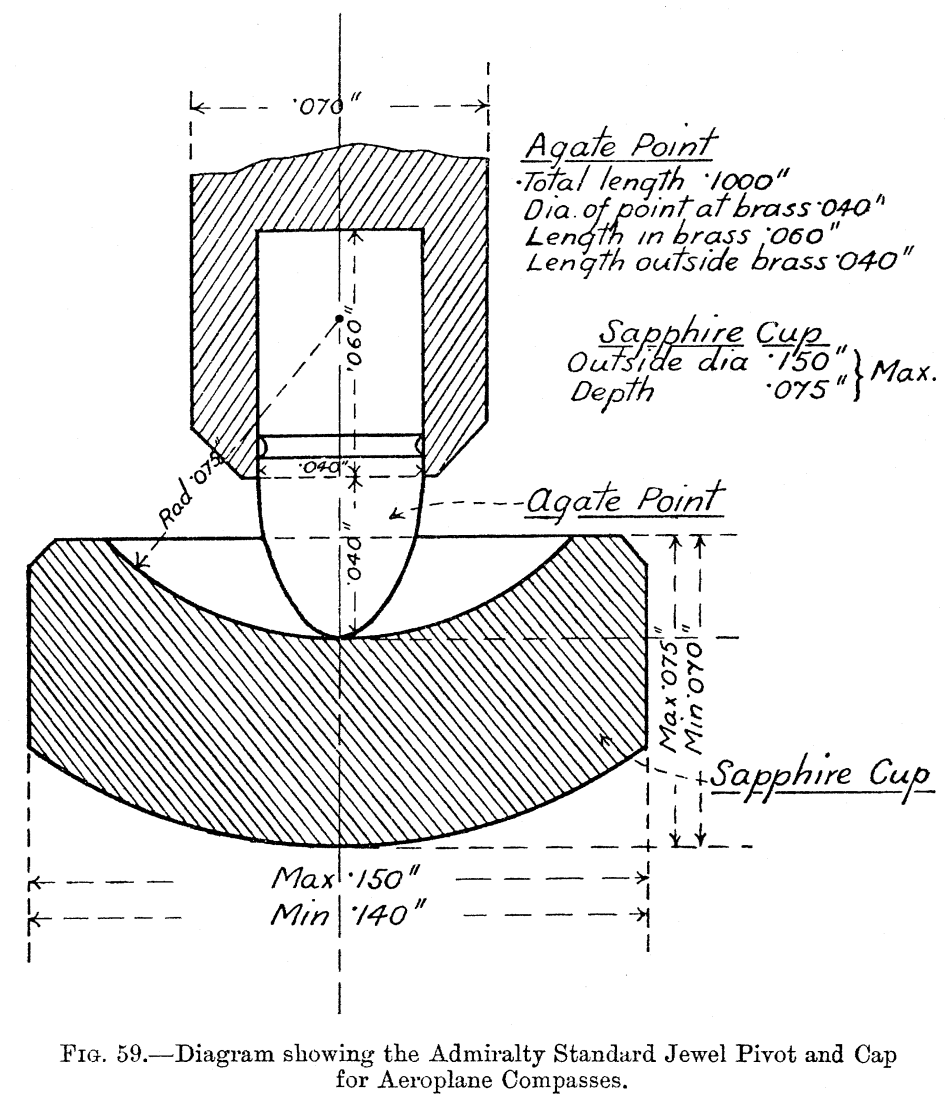

Fig. 5. Illustration from Bray (1917) showing the improved arrangement of agate point and sapphire cup for aircraft compasses, as recommended by the Geological Survey. 
Further requests from the Admiralty led to investigations into the liquid most suitable for filling the compass bowl, and on a coating suitable for protecting the paint of the compasscard. During September 1917 guidance was given to Fred Lee \& Company in Coventry, who had been making sapphire points for compasses, on a microscopical method for identifying agate of the appropriate quality. The agate-sapphire arrangement was subsequently adopted and a patent applied for by Fred Lee, who was purportedly commended by the Admiralty with the words: 'Mr. Lee you will have the satisfaction of knowing that you will be the means of saving hundreds of lives and your Country thousands of pounds' (GSM/DR/St/A/20: 'Extract from letter dated 22nd May 1918 from Mr Fred Lee’).

\section{Identifying sources of gravel used by the Germans in making concrete}

In April 1917, as part of a British offensive near Arras in northern France, Canadian troops captured Vimy Ridge, a heavily fortified seven-kilometre section of the Front. In September it was noticed that German concrete pill-boxes at the northern end of the ridge were made with gravel which could not have come from Belgium but was thought to have been sourced probably from the Rhine valley (King 1919, 214; Sabine 1991). By the middle of October it was being reported in British newspapers that the Netherlands, a neutral country, was allowing Germany to transport large quantities of stone, gravel and sand through Dutch waterways into Belgium to make concrete for trench reinforcements and pill-boxes. According to Article 2 of their neutrality declaration, the Dutch were obliged to ensure that the warring parties did not use neutral territory for the transport of military materials. The Dutch had been monitoring the transport of sand and gravel from Germany since at least November 1915, prompted by a series of articles in the anglophile Dutch newspaper De Telegraaf, which drew attention to incidents of smuggling (Abbenhuis 2006, 122-123). The Germans however provided documentation guaranteeing the civilian use of the materials for the legitimate repair of Belgian towns, bridges and roads damaged or destroyed by the war.

Britain now challenged this claim, and on 11 October all commercial cable communication with the Netherlands was suspended 'until such time as the Netherlands Government consents to put a stop to the transit of sand, gravel, and scrap metals through Holland from Germany to Belgium' (The Times, 12 October 1917). The closure of telegraph lines between Britain and the Netherlands caused disruption to the latter's commercial dealings, diplomatic communications, and contact with its East and West Indian colonies. In response, the Dutch Government agreed to discontinue the traffic if Britain could provide proof that the sand and gravel was being employed by the Germans for military purposes (The Times, 15 October 1917).

By about mid-October samples of concrete from captured German fortified positions (Fig. 6) were in the hands of the Geological Survey, which was tasked with determining, if possible, the sources of the aggregate employed in making the concrete (GSM/PT/A/27). Professor Stainier concluded that much of the aggregate was unlikely to have been sourced within Belgium. Perhaps the most critical evidence was provided by the presence of angular fragments and chips of Niedermendig lava, a distinctive rock type which could only have been quarried on the eastern slopes of the Eifel in Germany bordering on the Rhine (Strahan 
et al. 1917). Such was the significance of the Niedermendig evidence in assembling the case against Germany that Sir J. J. H. Teall (Fig. 1), a respected petrologist and former Director of the Geological Survey, was brought in to add his authority to its petrological identification (sample F2397, see Figs. 7 \& 8).

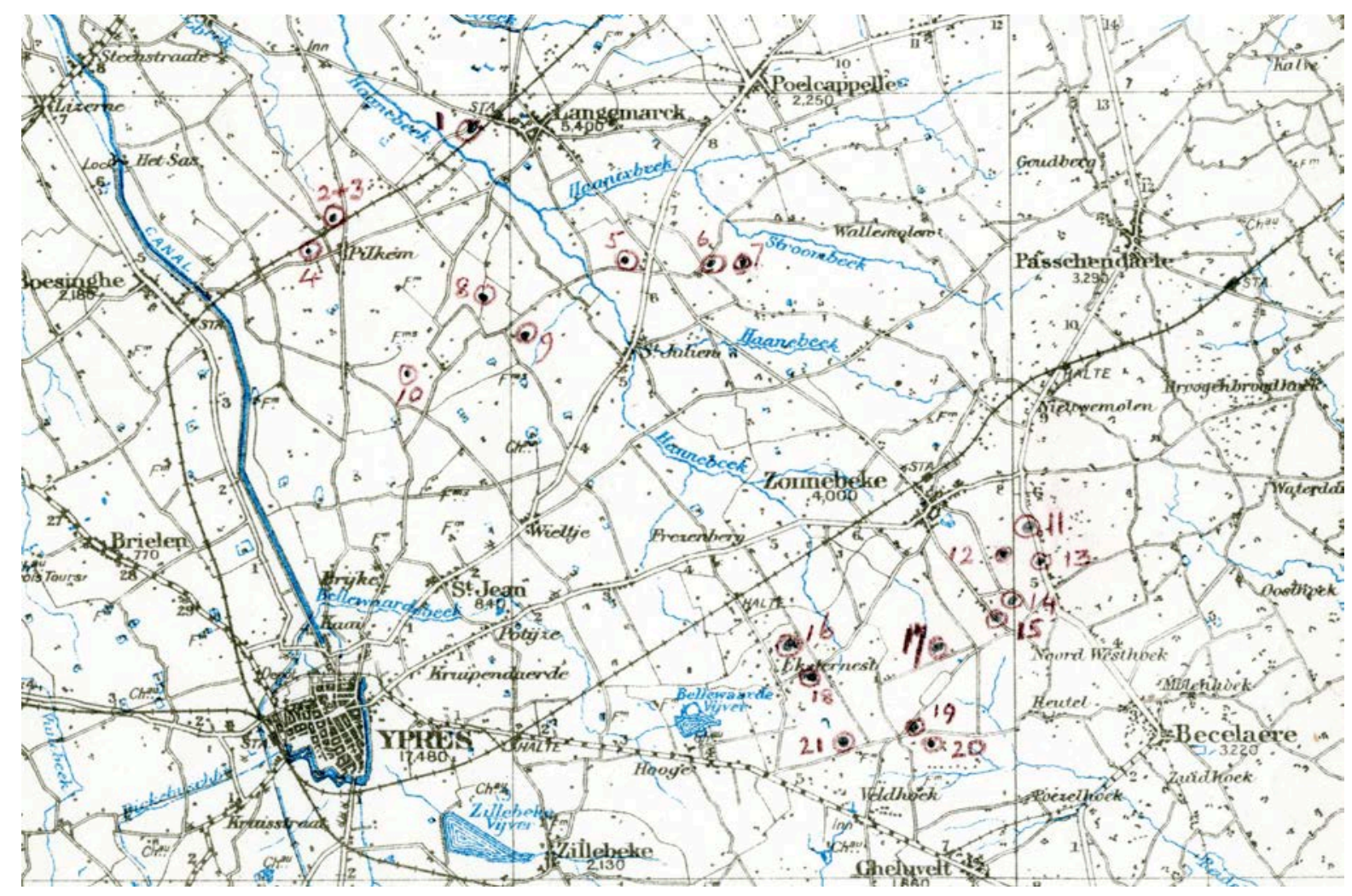

Fig. 6. Detail from a map of a section of the Western Front near Ypres, showing the location of specimens of German concrete collected by the Second Army in October 1917 and submitted to the Geological Survey for analysis (from Strahan et al. 1917).

The weight of evidence from several lines of enquiry now obliged the Dutch to threaten Germany with an indefinite suspension of sand and gravel carriage, leading the Germans to take a retaliatory stance. In the end, neither the Allies nor Germany had a wish for the Netherlands to enter the war, and a compromise was agreed. It has been said that of all the many neutrality concerns that affected the Dutch between 1914 and 1918, it was the German transport of sand and gravel that brought the Netherlands closest to war (Abbenhuis 2006, 135-138). The details of the case, incorporating evidence provided by the Geological Survey, were set out in two Parliamentary papers (Foreign Office 1917, 1918).

\section{Analysis of German cement from the Western Front}

The work of determining the provenance of aggregate used in German concrete, as described above, is a fine example of the application of geology to forensic science. A similar investigation (ultimately unsuccessful) was undertaken about a month later, in December 1917, when the Geological Survey was asked by the Director of Special Intelligence at the War Office to analyse samples of German cement from the Belgian front. This request arose in consequence of the recovery from captured German positions of paper bags and jute sacks carrying the words 'Portland cement'. British newspaper coverage suggested that British 


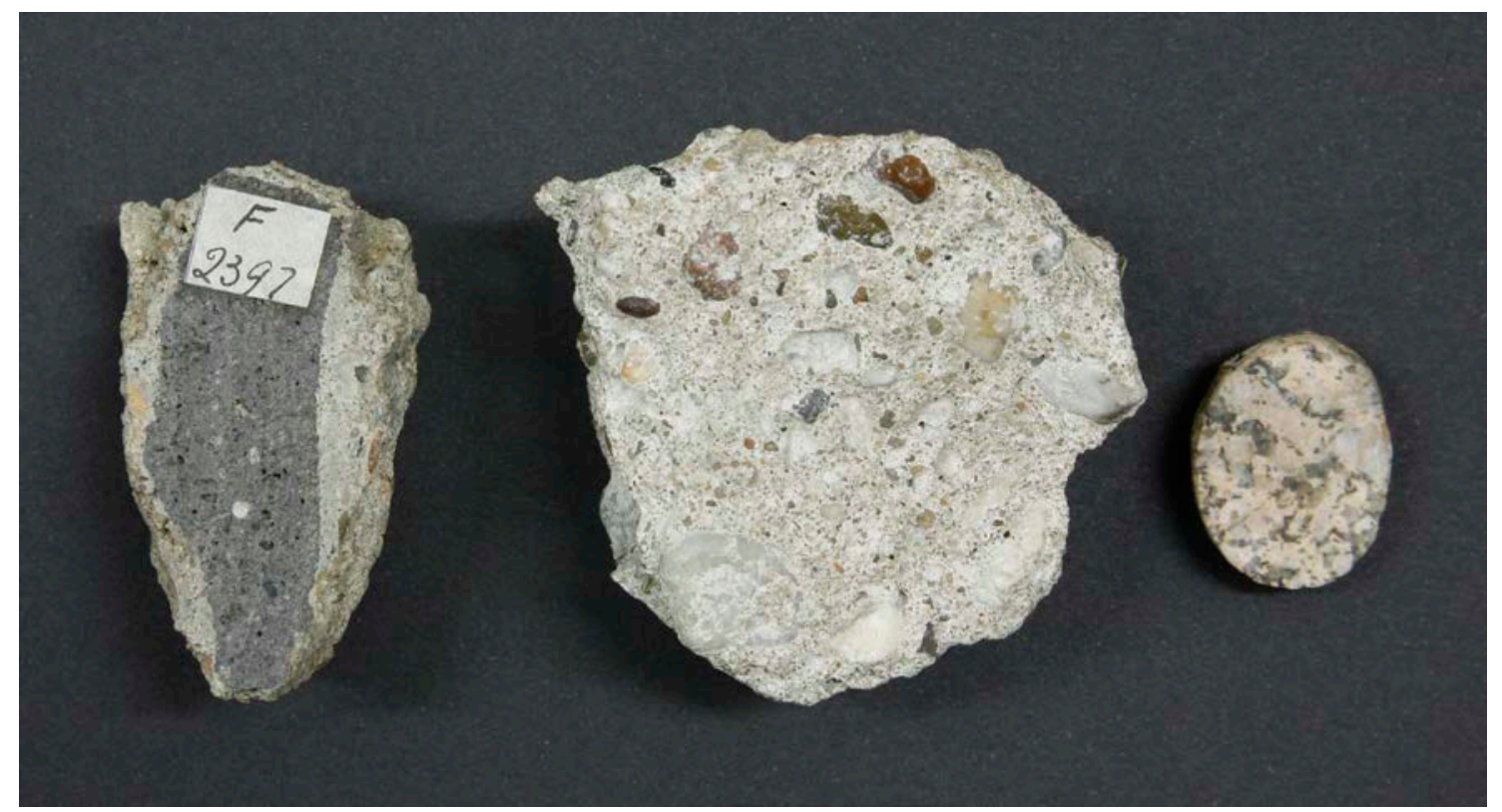

Fig. 7. Samples of aggregate and concrete taken from captured German positions at the Western Front; the samples were received from the War Office on 23 October 1917 and sliced for microscopical examination. Left: Niedermendig lava (F2397) set in concrete, collected by the Second Army, VIII Corps, from ESE of Pilckem (no 9 on map, Fig. 6). Centre: Concrete from Genoa, SE of Langemarck, containing pebbles of purplish decomposed olivine basalt, considered not to be of French or Belgian origin (F2386). Right: pebble of pink, moderately coarse granite similar in character to granite found at Rothwasser, near Freiburg and probably occurring in gravels of the Upper Rhine (F2390), collected by the Fifth Army from a dump of road metal at Pilckem.

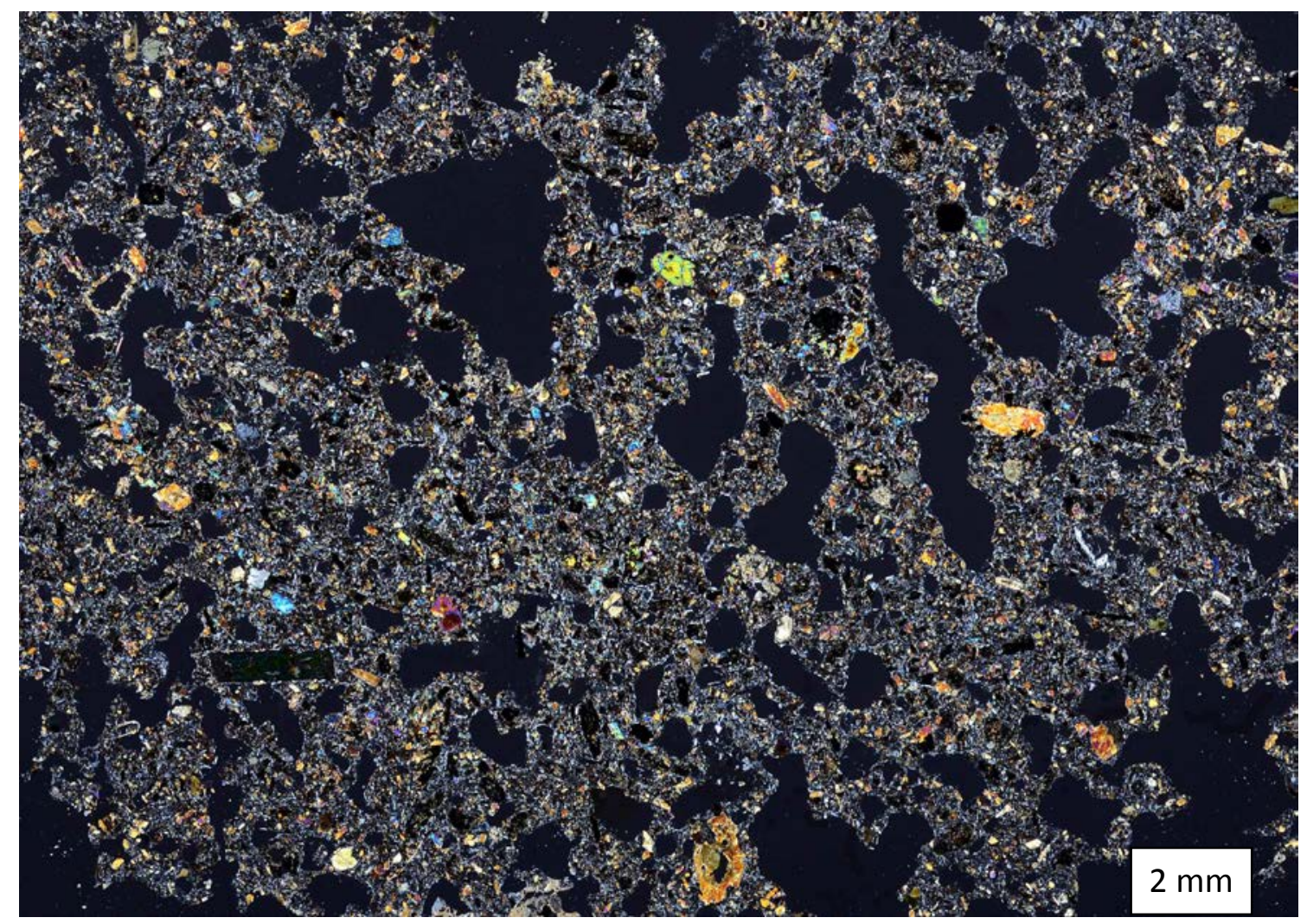

Fig. 8. Photomicrograph (viewed under crossed polars) of Niedermendig lava (F2397), a vesicular tephrite of Quaternary age, from the Eifel region of the Rhineland, Germany. 
cement imported into the Netherlands was being exported to Belgium for the construction of German military works. Captain R. P. Hewetson had written to The Times on 14 November stating that:

'...the pillbox in which I now write and which was built by the enemy is made of British cement. This I know by a small tin label which was dislodged from the middle of a thick wall by a shell; the label was embossed in English.'

This new accusation against the Dutch led to a demand that exports of British cement to the Netherlands be stopped, an action that would have impacted severely on that already beleaguered country.

The view of experts in the cement industry, such as the London based Cement Makers' Alliance, was that it would be impossible to distinguish the country of origin of any cement either by its appearance or by analysis of its composition (GSM/PT/A/27a: statements dated 8 November and 11 December 1917). During December the Geological Survey received samples of cement, pill-box concrete, bags and sack cloth from the Western Front for examination and chemical analysis. Many examples of cement and cement raw materials were obtained from manufacturers in all parts of Britain for the purpose of analytical comparison. But in January 1918 the Director of the Geological Survey confirmed that it was impossible by means of chemical analysis to distinguish cements made in different countries.

Valuable evidence however was obtained from a Monsieur Deroover, Managing Director of a long established cement manufacturing company based near Antwerp. As a one-time officer in the Belgian army he had been obliged to escape to the Netherlands, but maintained close contact with his co-Directors in Brussels. He provided a convincing argument against the likelihood of British cement being sold to the Germans, largely because German cement manufacturers insisted on being sole suppliers to the German army. It was further pointed out that the Germans had commandeered cement works in Belgium, where they could obtain cement more cheaply and closer to hand. In regard to the leaden sack seal mentioned by Capt Hewetson, it was reported in The Times on 29 November that the wording on one side read 'Cannon Brand, Artificial Portland', and on the other 'Burcht, Antwerp'. The term 'Portland Cement' was widely employed by German cement manufacturers and all of the branded cement bags brought back from the Western Front bore the names of German or Belgian factories. Pieces of sacking submitted to two experienced British sack manufacturers were assessed by them as being not of British manufacture (GSM/PT/A/27a). The matter is briefly discussed by Oldham $(1995,18)$, although he does not give sources for some of his more significant statements.

\section{Choice of stone for war graves}

A decision was taken by the British authorities early in the war that there should be no repatriation of soldiers who died, and that they should be buried as close as possible to the site of the action in which they were killed (Doyle 1998). During the course of the war, burial sites were marked with temporary wooden crosses, which appeared in large numbers on the battlefields of France, Belgium and beyond. The Imperial War Graves Commission (now the 
Commonwealth War Graves Commission) was established by Royal Charter in May 1917, having existed previously as the Graves Registration Commission. One of its tasks was to find a suitable stone for headstones and other memorials to replace the wooden crosses.

On 27 June 1918 a request was received by the Geological Survey from the Commission asking if a stone similar to the 'Lunel clair' (Carboniferous Limestone series) of the Vallée heureuse quarry, Marquise, France, could be found in England (GSM/QR/G/39). In reply it was stated that the only quarries capable of providing a stone approaching the Lunel clair in quality and appearance were those of Hopton Wood in Derbyshire, England. The

Commission followed on 29 June with an urgent request that an expert geologist be sent to investigate the Lunel clair quarry. A further letter outlined in more detail the purpose of the investigation, which was to determine whether the stratum containing this stone could provide material of consistent quality for 500000 headstones measuring 38 x 90 x $8 \mathrm{~cm}$, and 300 large monoliths measuring 12 feet by 2 feet $9 \frac{1}{4} 4$ inches by 3 feet 6 inches. Mr J. Allen Howe (Fig. 1), Curator at the Geological Survey and Museum and an established authority on the geology of building stones (Howe 1910), was accordingly despatched on 5 July, and on the following day arrived at the quarry and works of the Société des Carrières de la Vallée heureuse et du Haut Banc.

Howe concluded in his report (Howe 1918) that the amount of usable stone available in the quarry should be sufficient for the intended purpose, provided it was acceptable to employ the variety Lunel rosé in addition to the Lunel clair. Other stones lying within the Paris basin were also considered from the point of view of economy of transport. In the meantime, the Geological Survey conducted some tests on Light Grey Hopton Wood Stone (Carboniferous Limestone series) to determine its suitability for acid engraving. Discussions about a suitable stone were still ongoing a year later, when the advice of the Geological Survey was sought concerning the suitability of sample stones from Malta (a foraminiferal limestone of supposed Oligocene age), and the Forest of Dean in England (Carboniferous sandstone).

By 1920 a decision had been taken by the Commission to employ Portland Stone, a whitegrey limestone of Late Jurassic (Tithonian) age, which has long been quarried on the Isle of Portland, Dorset, England. For some years after the war the Geological Survey continued to receive requests for advice on a variety of alternative stones for war graves and memorials. It is clear from the correspondence that several other British stones were employed by the Commission for individual cemeteries. These include Grinshill Stone (Triassic sandstone, Shropshire, England: this was used at one cemetery in France, the location of which is not stated), and Robin Hood Stone (Carboniferous sandstone, Yorkshire, England: used at several cemeteries in France and Belgium, though the colour and general appearance did not meet with approval). Other stones are mentioned, including Greenbrae, Blue York and Woodkirk, although it is unclear if any of these were used for war cemeteries outside the United Kingdom. Ultimately, Portland and Hopton Wood stones were settled upon as the Commission's preferred choice.

It is unclear whether the Lunel clair stone was employed by the Commission, but it is evident from the files that a number of French stones were used. These include Euville Marbrier, 
Brauvilliers Liais and Pierre Romaine de lens, all of which are Jurassic limestones. Other French stones that were being considered between 1924 and 1926 include Crazannes (Cretaceous limestone), 'Montfort' (from quarries south of Grenoble), 'Lecon' (from quarries $50 \mathrm{~km}$ north of Marseilles), 'Morley Javot' (quarried in the commune of Morley, adjoining that of Brauvilliers), and 'Lérouville Moulin à vent' (proposed in May 1926 for the large Indian memorial at Neuve Chapelle).

\section{Miscellaneous activities}

Strahan (1919; GSM/DR/St/A/32) lists a number of other wartime activities that were conducted in response to requests from the War Office, Admiralty, Air Ministry, Ministry of Munitions, and War Trade Intelligence Department, although, except where indicated, few or no details appear to have been retained in the British Geological Survey archives. These include:

(i) Consultations on the making of tube-wells and the use of sand-screens in boreholes, June 1916; for background to this see T. W. Edgeworth David, in Rose (2015, 9-13);

(ii) Report on underground water levels in the Chalk, September 1916; the matter assumed some importance in August to September 1916 in connection with military mining operations at the Front (Institution of Royal Engineers 1922, 23-28);

(iii) Preparation of sets of characteristic fossils of certain formations for use at the Western Front, December 1916;

(iv) Consultations on the construction of seismographs for locating camouflets, March 1917;

(v) Report on the mineral resources of Austria-Hungary, July 1917;

(vi) Reports on selection of quartz crystals for submarine detectors, 1917-18, including a visit by H. H. Thomas to France in 1918 to examine and report upon a consignment of quartz crystals from Madagascar: a five-page report in French, 'Note sur le quartz transparent de Madagascar’ was placed on file (Petrographical Reports, vol. XVII);

(vii) Consultations as to sites for aerodromes, July 1917;

(viii) Report on causes of sores on the hands of tunnellers working in Ypresian clay, July 1917;

(ix) Report to Munitions Inventions Department (Ministry of Munitions) on sources of zircon, March 1918 (GSM/DR/St/A/36): on 11 February the Survey was asked to identify a mineral captured from a German cargo, which proved to be zircon (Petrographical Reports, vol. XVII);

(x) Report on squeezing out of clay in the walls of dug-outs, March 1918; the matter is discussed at length by T. W. Edgeworth David, in Institution of Royal Engineers (1922, 4043);

(xi) Report as to suitability of sand for making concrete at Western Front, March 1918;

(xii) Advice to the Foreign Office on hexahedric pyrite crystals (1918), following the discovery that the Germans were attempting to purchase supplies in Japan: it was speculated that the material was being used as coherers in wireless telegraphy. 
Strahan also records the preparation of geological maps and sections of the Le Cateau and Aisne battlefields, but no further information is known.

John Smith Flett, who in 1920 succeeded Strahan as Director of the Geological Survey, later mentioned another unusual line of enquiry, which he reports simply as 'selenium and dark rays' (Flett 1937). This interest may be connected with the fact that between February and October 1916, Dr A. O. Rankine of the Department of Physics, University College London, had been conducting extensive experiments in lightwave communications for the Admiralty. Rankine's transmitter employed selenium detectors, which had a limited frequency response. In October 1917 the American chemist, physicist and inventor, T. W. Case, was able to demonstrate a thallium-based photoconductive cell, which had a spectral response that made it more suitable than selenium cells for covert infrared communication. The Germans at this time were also attempting to develop lightwave communicators for military purposes (Mims 1994).

\section{Concluding remarks}

In an address delivered on 12 December 1916, the Director of the Geological Survey, Aubrey Strahan, noted that prior to the start of the war there had been a perception that the work of the stratigraphical geologist, the palaeontologist and the petrographer had warranted only a respectful toleration in Britain - a luxury, to be abandoned first among luxuries in a time of stress (Strahan 1917b). The war changed all of this. Within days of Britain's entry into the conflict the services of the Geological Survey were called upon to provide basic geological information in relation to the European theatre of war. Yet only as the war progressed did the British Government come to a full appreciation of the potentially wide-ranging application of geology to the war effort.

By the end of the war Strahan could report that twenty-nine members of staff of the Geological Survey and Museum had served with the forces (Strahan 1919). This number was drawn from fourteen Geologists, one Assistant Clerk, three Fossil Collectors, two General Assistants, three Attendants, four Draughtsmen, and two Labourers. All returned, though about one third of their number sustained wounds. Geologist C. H. Cunnington was invalided home in October 1917 after serving first at Gallipoli and afterwards at the Front in France. He died of his injuries in April 1918, aged twenty-eight (Lamplugh 1920). E. B. Bailey, who would later go on to become Director of the Survey, was twice wounded and lost an eye in France, which earned him the irreverent nickname 'Cyclops’ (Wilson 1985, 23).

In regard to the value of geological expertise in warfare, we may usefully quote the words of Lieutenant-Colonel Sir T. W. Edgeworth David and Captain W. B. R. King, two of the most distinguished military geological advisers during the First World War (Fig. 3). The following is taken from the final paragraph of the The work of the Royal Engineers in the European war, 1914-19: geological work on the Western Front (Institution of Royal Engineers 1922):

While it is not suggested that Geologists should necessarily belong to the Regular Army in peace time, it is certainly desirable that such touch should be kept with H.M. Geological 
Survey, and such machinery exist, as will ensure the presence of a geological staff with any future British Army from the outbreak of hostilities.

The Survey did indeed support Allied armed forces to a significant extent in the Second World War (Bailey 1952; Mather 2012; Rose \& Rosenbaum 1993b), but it was not until after the war, in 1949, that a pool of geologists was created within the Royal Engineers branch of the British reserve army (Rose \& Hughes 1993). Transformed and renewed over subsequent decades, equivalent expertise is still to be found there (Rose \& Rosenbaum in press).

\section{Acknowledgements}

We would like to thank Ted Rose for commenting on an early draft of this paper and for so willingly providing copies of a number of his published papers. Both he and an anonymous reviewer are also thanked for their detailed comments on the final draft. Any failings that remain, however, are those of the authors. Chris Wheatley, long time former curator of the BGS rock collections, is thanked for locating registered samples of concrete and aggregate from the Western Front, illustrated in Fig. 7, and for supplying associated documentation. Simon J. Harris, Conservator at the BGS, was kind enough to supply a photomicrograph of the thin section of Niedermendig lava which appears as Fig. 8, while Steve Parry, BGS Mineralogist/Petrographer, kindly confirmed its identity as a tephrite. Fig. 3 was most generously supplied to us by Jane Ritchie, the granddaughter of Bill King. All other figures were prepared (scanned or photographed) by David Bate from materials held at the British Geological Survey (Figs. 1, 2, 4, 6 \& 7) and the British Library (Fig. 5).

\section{References}

Abbenhuis, M. M. 2006. The art of staying neutral: the Netherlands in the First World War, 1914-1918. Amsterdam University Press, 423 pp.

Bailey, E. B. 1952. The Geological Survey of Great Britain. London: Thomas Murby.

Bergerat, F., Blieck, A., Vigouroux, P. \& Porchier, J.-C. (editors; in press). 14-18: Géologie et géologues sur le front occidental. Paris: l'Association des géologues du Bassin de Paris, Le Comité français d'histoire de la géologie, La Société géologique du Nord.

Bray, R. J. 1917. Pivots and caps in compasses. London: HMSO, 78 pp.

Doyle, P. 1998. Geology of the Western Front, 1914-1918. Geologists’ Association Guide, no 61, 80 pp.

Flett, J. S. 1928. Obituary notice: Sir Aubrey Strahan, 1852-1928. Proceedings of the Royal Society, Series B 103, xvi-xx, plate.

Flett, J. S. 1937. The first hundred years of the Geological Survey of Great Britain. London: His Majesty’s Stationery Office, pp. 161-170: The Geological Survey under Sir Aubrey Strahan.

Foreign Office (Great Britain) 1917. Correspondence respecting the transit traffic across Holland of materials susceptible of employment as military supplies. London: HMSO, Cd. 8693, Miscellaneous no. 17 (1917), 14 pp.

Foreign Office (Great Britain) 1918. Further correspondence respecting the transit traffic across Holland of materials susceptible of employment as military supplies. London: HMSO, Cd. 8915, Miscellaneous no. 2 (1918), 180 pp + folding map. 
Howe, J. A. 1910. The geology of building stones. London: Edward Arnold, 455 pp.

Howe, J. A. 1918. Report on the "Lunel clair" stone from the quarries of the Vallée Heurèuse, Hydrequent-Rinxent (Pas-de-Calais) France. Geological Survey of Great Britain, unpublished typescript report, 10 July 1918, [8] leaves + hand-coloured map (GSM/QR/G/39)

Institution of Royal Engineers 1921. The work of the Royal Engineers in the European war, 1914-19: water supply. Chatham: Royal Engineers Institute.

Institution of Royal Engineers 1922. The work of the Royal Engineers in the European war, 1914-19: geological work on the Western Front. Chatham: Institution of Royal Engineers.

King, W. B. R. 1919. Geological work on the Western Front. Geographical Journal 54 (4), 201-221.

Lamplugh, G. W. 1920. [Obituary:] Lieut. C. H. Cunnington. Quarterly Journal of the Geological Society, London, 75 (1), li-lii.

Mather, J. D. 2012. War as a catalyst for change: groundwater studies in the Geological Survey of Great Britain before 1950 and the impact of two World Wars. In: Military aspects of hydrogeology, edited by E. P. F. Rose \& J. D. Mather. Geological Society Special Publication 362, 139-159.

Mims, F. M. 1994. The first century of lightwave communications (Part II). In: Fiber optics primer. Boston, MA: Information Gatekeepers Inc, Fiber Optic Reprint Series 28, 6-10.

Oldham, P. 1995 (re-issued 2011). Pill boxes on the Western Front: a guide to the design, construction and use of concrete pill boxes 1914-1918. Barnsley: Pen \& Sword, 208 pp.

Rose, E. P. F. 1996. Geologists and the army in nineteenth century Britain: a scientific and educational symbiosis? Proceedings of the Geologists’ Association 107 (2), 129-141.

Rose, E. P. F. 2009. Water supply maps for the Western Front (Belgium and northern France) developed by British, German and American military geologists during World War I: pioneering studies in hydrogeology from trench warfare. Cartographic Journal 46 (2), 76 103.

Rose, E. P. F. 2012. Groundwater as a military resource: pioneering British military well boring and hydrogeology in World War I. In: Military aspects of hydrogeology, edited by E. P. F. Rose \& J. D. Mather. Geological Society Special Publication 362, 49-72.

Rose, E. P. F. 2015. Geology at the Western Front: T. W. Edgeworth David. Earth Sciences History 34 (1), 1-22.

Rose, E. P. F. \& Hughes, N. F. 1993. Sapper geology: Part 2. Geologist pools in the reserve army. Royal Engineers Journal 107, 173-181.

Rose, E. P. F. \& Rosenbaum, M. S. 1993a. British military geologists: the formative years to the end of the First World War. Proceedings of the Geologists’ Association 104 (1), 4149.

Rose, E. P. F. \& Rosenbaum, M. S. 1993b. British military geologists: through the Second World War to the end of the Cold War. Proceedings of the Geologists' Association 104 (2), 95-108.

Rose, E. P. F. \& Rosenbaum, M. S. (in press). Sapper geology: Part 4. Royal Engineer Specialist Advisory Team geologists. Royal Engineers Journal. 
Sabine, P. A. 1991. Geologists at war: a forensic investigation in the field of war-time diplomacy. Proceedings of the Geologists’ Association 102 (2), 139-143.

Strahan, A. 1914. Notes on sources of temporary water supply in the south of England and neighbouring parts of the Continent. London: Geological Survey and Museum, 13 pp.

Strahan, A. 1915a. Report on the geological conditions affecting the available sources of water in Belgium and the north of France. Geological Survey of Great Britain, unpublished typescript report, July 1915, [2],47 leaves + 3 leaves of figs (GSM/DR/St/A/11)

Strahan, A. 1915b. Geological map of Belgium, scale 1:160,000; geological lines prepared and modified by the Director, Geological Survey, from the Carte Géologique de la Belgique, 1:40,000 scale. [Southampton]: Ordnance Survey Office, G.S.G.S. 3072, 5 sheets, hand coloured.

Strahan, A. 1917a. In: Summary of Progress of the Geological Survey of Great Britain and the Museum of Practical Geology for 1916.

Strahan, A. 1917b. Geology at the seat of war. Geological Magazine dec 6, 4 (2), 68-74.

Strahan, A. 1919. Work in connection with the War. Summary of Progress of the Geological Survey of Great Britain and the Museum of Practical Geology for 1918, 1-4.

Strahan, A., David, T. W. E. \& King, W. B. R. (with appendices by X. Stainier, J. J. H. Teall, A. Harker \& H. H. Thomas) 1917. Report on specimens of German concrete from Flanders and on the material used in making it. Geological Survey of Great Britain, unpublished typescript report, 1 November 1917, [17] leaves + map (GSM/PT/A/27)

Wilson. H. E. 1985. Down to earth: one hundred and fifty years of the British Geological Survey. Edinburgh: Scottish Academic Press.

Manuscript sources: British Geological Survey Archives

GSM/DC/P/37: Staff organization, general, 1914-54 (various unsystematic papers).

GSM/DR/St/A/3: War Office: water in north of France and Belgium, 1914.

GSM/DR/St/A/11: War Office: report on sources of water in Belgium and north of France, 1915.

GSM/DR/St/A/16: Lieut. W. B. R. King: water supply in front of British line on Western Front, 1916.

GSM/DR/St/A/20: Admiralty: points for aeroplane compass, 1916-19.

GSM/DR/St/A/32: Report on the activities of the Geological Survey of Great Britain, 191418.

GSM/DR/St/A/36: Ministry of Munitions: sources of zirconia, 1918.

GSM/PT/A/27: German concrete: report on specimens for the War Office and Foreign Office, 1917-18.

GSM/PT/A/27a: War Office: samples of cement from Western Front for analysis, 1917-18.

GSM/QR/G/39: Imperial War Graves Commission: as to suitable stones for war graves, 1918-30. 